\title{
Pragmatism of the Alcoholics Anonymous Fellowship
}

\author{
Marek A. Motyka ${ }^{1} \&$ Ahmed Al-Imam ${ }^{2}$ \\ ${ }^{1}$ Institute of Sociological Sciences, University of Rzeszów, Rzeszów, Poland \\ ${ }^{2}$ Department of Anatomy and Cellular Biology, College of Medicine, University of Baghdad, Iraq \\ Correspondence: Ahmed Al-Imam, Department of Anatomy and Cellular Biology, College of Medicine, \\ University of Baghdad, Iraq. E-mail: tesla1452@gmail.com
}

Received: March 5, 2020 Accepted: April 9, 2020 Online Published: April 27, 2020

doi:10.5539/gjhs.v12n6p119 URL: https://doi.org/10.5539/gjhs.v12n6p119

\begin{abstract}
Alcoholics Anonymous is a fellowship of people addicted to alcohol, who share their experience from the period of drinking, but who primarily have ongoing personal struggles with unstable emotions, a disintegrated value system, broken social ties, and other consequences of their old lifestyle. Participants of AA meetings provide mutual support at every stage of recovery and gain hope for improvement in their situation. Acceptance and implementation of the principles of the AA Programme promote recovery and improvement in all areas of life. It helps achieve physical health, emotional stability and better social relations, and creates a stable normative system. Joining the AA Fellowship is very useful for almost every member. The principles and objectives of the AA Fellowship were inspired by American pragmatism. The article presents the constitutive features of this philosophical trend, the inspirations which the founders of the AA Fellowship followed, and data supporting the usefulness of the 12 Steps of AA in recovery from alcoholism.
\end{abstract}

Keywords: alcohol addiction, self-help groups, William James, utility, recovery

\section{Introduction}

Alcohol dependence is a progressive, chronic, insidious, and above all fatal disease (Bettinardi-Angres \& Angres, 2010). It is progressive because it develops for several years or decades; it is chronic because the return to drinking even after a long period of abstinence usually exaggerates all disease symptoms and patterns of addictive behavior (Woronowicz, 2009); it is insidious because a person who develops this disease for many years may not be aware of being ill (due to the effects of psychological defense mechanisms) (Mellibruda \& Sobolewska-Mellibruda, 2006); it is fatal because when untreated it leads to death in many cases (World Health Organization [WHO], 2018). Alcoholism has debilitating consequences in all areas of life, both physical and mental (Trevisan, Boutros, Petrakis, \& Krystal, 1998), and causes a transformation in the value system and the social environment of the alcoholic (Mellibruda, 1997; Wnuk \& Marcinkowski, 2012). Ireneusz Kaczmarczyk defines alcohol dependence as a disease of dignity, manifested in the violation of social norms by an alcoholic, who over time loses self-esteem, perceives himself/herself as a person inferior to others, and with the progression of the disease gradually loses faith in the sense of life (Kaczmarczyk, 2012).

Jerzy Mellibruda (1997) identified the following key problems in people addicted to alcohol:

- Progressive self-destruction indicating serious dysfunction of the self-preservation instinct: the alcoholic keeps drinking alcohol despite being aware of the damaging effects of abuse on health, family, and social relationships;

- Development of the alcohol craving: a strong need or compulsion to drink alcohol that occurs especially in situations of emotional arousal, in circumstances related to alcohol consumption, or after consuming even a small volume of alcohol;

- The impairment and consequential loss of control over the volume of alcohol consumed, or refraining from drinking it, as well as more frequent failures during attempts to stop drinking;

- A growing sense of helplessness, suffering, and loneliness;

- The concentration of the addict's life on the circumstances and matters associated with drinking alcohol, and deterioration or discontinuation of existing social relations (social contacts are almost exclusively limited to a group of people having a similar lifestyle, spending free time almost exclusively drinking, 
planning to drink, making alcohol supplies, etc.);

- Ignorance of social norms and the value system in circumstances that conflict with the current needs of the addicted person (breaking promises, committing fraud, marital infidelity, etc.) (Mellibruda, 1997).

Alcohol dependence causes severe damage. Difficulties with performing basic social roles emerge in the early stages of alcohol dependence. As the disease develops, progressive dysfunction - as Jakub Trzebiatowski argues "affects the subuniverses of the alcoholic's life in a global perspective. In family life alcoholics gradually withdraw from their former activities, e.g. picking up children from kindergarten or school, or doing cleaning or shopping. The individual's activity in the family subuniverse, both in the family of origin and the family of procreation, changes significantly. An alcoholic has more and more difficulty when it comes to performing professional roles. Also, involvement in social relations such as being a friend or acquaintance gradually decreases. Thus, the subuniverse of an active disease takes over the control of the other subuniverses, and becomes the basic reality" (Trzebiatowski, 2014).

Particularly severe damage occurs in the structure of the "Self"; in perceiving oneself and one's own ability to control life and all its aspects, in creating a dualistic image of the self, both as a person following generally acceptable principles of social life in periods of abstinence, as well as an individual ready and able to offend these principles in drinking periods (Mellibruda, 1997). Many years of alcohol abuse, together with all its consequences which the addicted person experiences, e.g. guilt, failure, ongoing shame and a growing sense of loneliness, deprives the alcoholic of dignity while reducing his/her self-esteem (Burak, Dembna, Cierzniakowska, Zacniewski, \& Popow, 2016).

Therapeutic work with an addicted person includes not only searching for ways to stop drinking alcohol, but primarily focuses on rebuilding the value system, a coherent self-image, and restoring a sense of coherence and life satisfaction (Ryszkowski, Wojciechowska, Kopański, Brukwicka, Lishchynskyy, \& Uracz, 2015). One method helping to restore the bodily, emotional and social balance, and especially to restore self-esteem in an addicted person is the 12 Steps Programme of Alcoholics Anonymous (Mellibruda, 1997; Montalto, 2015).

\section{The Alcoholics Anonymous Fellowship}

Alcoholics Anonymous (AA) is a fellowship that for over 80 years has been helping alcoholics in achieving sobriety. The General Service Office of Alcoholics Anonymous (2019) has estimated that mutual aid groups of Alcoholics Anonymous meet in 180 countries (over 2 million members), which confirms the considerable value of this type of interaction between people struggling with the consequences of alcohol dependence. The AA Fellowship proposed constructive changes in the 12 Step Programme, which is uncomplicated and possible to follow for any person who declares a desire to stop drinking alcohol and accepts the principles of this program (Woronowicz, 2009).

AA was founded in 1935 in Akron, Ohio (US), when one alcoholic, a stockbroker, William G. Wilson, sought help on how to stay sober and talked to another alcoholic, Dr. Robert H. Smith, who was no longer able to work because of his alcohol abuse (Gross, 2010; Jannasz, 2018). Kaczmarczyk (2012) argues that the transformation of W.G. Wilson was initiated after he had read writings by William James, a proponent of pragmatism, especially fragments of his works on religious experience. Wilson was considered a hopeless alcoholic, for whom - according to one of the doctors trying to help him - only a deep spiritual transformation could give a chance to improve life. It was the inspiration from the cases presented by W. James in Varieties of Religious Experience that stimulated deep reflection and then the transformation in the life of W. G. Wilson, who had earlier taken many specific and consistent measures to help himself (Kaczmarczyk, 2012).

But to attribute the foundation of the AA Fellowship to an accidental meeting of two alcoholics would be too simplistic and would ignore key facts for both the establishment of this Fellowship and the principles proposed to its members in the 12 Steps program. It would also be far too simple to assume that only participation in meetings of Alcoholics Anonymous can contribute to the significant changes in the life of an alcoholic.

\section{Views of William James and the AA Fellowship}

Researchers analyzing the influences of Alcoholics Anonymous emphasize the links between the Fellowship and pragmatism - a philosophical trend coined in the $20^{\text {th }}$ century by Charles S. Peirce (Broszkiewicz, 2012) and popularised by William James (Śliwowska, 2009; Knapik, 2012). The main subject of this philosophy indicated by its creators was the human being, or rather, as Jerzy Szacki puts it, "the conception of a human being that leaves no room for his image as a finished product of nature, nor for the concept of a tabula rasa passively exposed to the natural or social environment. The human being becomes what he or she is through interactions with the environment which is, of course, also created by other organisms" (Szacki, 2007). Pragmatists pointed out that the 
social universe is constructed precisely through the interactions between individuals co-creating reality, in which they actively participate and at the same time create. William James argued that "the knower is an actor, and co-efficient of the truth on one side, whilst on the other he registers the truth which he helps to create" (James, 1920).

John Dewey, one of the most prominent proponents of pragmatism, wrote that "Society is the process of associating in such ways that experiences, ideas, emotions, values are transmitted and made common" (Dewey, 1950), while an individual is "a blanket term for the immense variety of specific reactions, habits, dispositions and powers of human nature that are evoked, and confirmed under the influences of associated life" (Dewey, 1950). All observed experiences of others (selected in the mind of the individual and assimilated as one's own) are examples of utility, of pragmatism, which promotes the creation of individuality from collective experiences, universalism making the use of principles possible (in this case the 12 Steps Programme) for members of all social classes, all nationalities, and different cultures.

The significant role of interactions between individuals acting together to promote sobriety was noticed in the early years of the AA operation. Founders of the AA Fellowship emphasized the practical and utilitarian aspects of meetings and the experiences discussed during them, appreciated the value of sharing experience between the participants of regular gatherings, and encouraged the internalization of the principles included in the 12 Steps of AA. The overarching goal and the essence of introducing constructive changes in the life of an alcoholic were to return to his or her basic social roles - naturally by referring to these principles - but above all improving the family, social and economic situation, and at the same time increasing self-esteem, life satisfaction, and improving health (Woronowicz, 1992).

Advocates of pragmatism "rejected definitions of society other than as a set of interacting individuals" (Szacki, 2007). The Alcoholics Anonymous Fellowship operates following these principles: a newcomer to a community (in this case the AA group) uses the capital of this group but also contributes his/her own capital, which is experiences, emotions or capacities, which can be used, depending on their utility, by that individual or by other members of the group.

The constitutive principles of the Alcoholics Anonymous Fellowship referred to works by the previously mentioned William James, considered the founder of American psychology, who as a scholar explored the religious experiences of people, was interested in the problems of values, spirituality, will and awareness, and in his work as a therapist combined psychology with religion and the spiritual aspects of human life (Taves, 2009; Kaczmarczyk, 2012). James noticed that each transformation that individuals experience was preceded by dramatic events occurring in their lives. However, for William James, as an advocate of pragmatism, the reason for these dramatic events was not important, but the final result of the identified metamorphosis (William James and Alcoholics Anonymous, 2013). Important to him were the spectacular effects observed in patients, which led to equally spectacular changes inside them, and also in their lives.

Tomasz Knapik argues that pragmatism "is a philosophy that postulates a practical way of thinking and acting in every situation, making the veracity of the statements dependent on their practical implications, and thus adopts utility as the criterion of truth" (Knapik, 2012). The concept of truth, an important issue in pragmatism, also serves as a research method for the proponents of this philosophy. When addressing this criterion James wrote: "To attain perfect clearness in our thoughts of an object, then, we need only consider what conceivable effects of a practical kind the object may involve. Our conception of these effects, whether immediate or remote, is then for us the whole of our conception of the object" (James, 1998). James argues that the truth is a relational property; it is a kind of relationship between reality and theory. The veracity of theories can only be tested by confronting those theories with reality, and for James, the reality was both the world surrounding the man and the whole of human experience (Śliwowska, 2009). The creed of Jamesian pragmatism was aptly paraphrased by Zbigniew Drozdowicz: "pragmatism is about the truth, which is apprehended as the compatibility of our ideas with reality, the truth which is the property of some of our ideas. For pragmatists, the true ideas are those that we can assimilate, justify, confirm and verify, and every truth that helps us deal with a certain reality, practically or intellectually, is something that belongs to this reality. [...] And whether an idea has a practical use or not it depends on whether it helps us or not in dealing with some particular reality or some aspects of this reality, either practically or intellectually. Either way, not only must the idea emerge, but also the action that will determine the meaning of truth. Hence, it can be concluded that the creed of pragmatism (from Greek prágma - deed) is reflected in focusing on action, or at least deciding on everything that is most important in action" (Drozdowicz, 2010).

For people struggling with alcohol dependence, the 12 Steps Programme is a set of ideas that can help improve their quality of life, but only if they accept them. And acceptance is only possible by modeling the individual's 
motivation to accept the proposed ideas through the observation of other people whose lives have improved because they complied with these principles. For this reason, Alcoholics Anonymous attaches much attention to regular participation in their meetings, engagement in activities of Services, work on the implementation of the 12 Steps, and especially cooperation with the Sponsor - a person who has internalized the principles of the AA program, for whom the proposed ideas are unquestionable in terms of effectiveness (Vaillant, 2005). The veracity of the AA Programme may often be questioned by 'newcomers' because of the defense mechanisms which develop in alcoholics (the mechanism of illusion and denial, and the mechanism of the dual and diffuse "Self"), which are intensified and developed at the initial stage of sobriety (Mellibruda \& Sobolewska-Mellibruda, 2006).

For Alcoholics Anonymous, making constructive changes relies on honest and open talking about oneself, sharing experiences, and constructing a value system common for all those interested in seeking solutions to problems. The 'new way' consists in learning the acceptance of things that cannot be changed in one's life, generating the courage to make changes wherever possible, as well as - through membership in the Fellowship - acquiring wisdom that will help the alcoholic identify what can be changed and what will never change; admitting the irreversible loss of control over drinking, and orientation towards the improvement of one's situation instead of being focused on attempts to control drinking. These guidelines are internalized with each participation in the AA meeting, to become the motto repeated by many recovering alcoholics at the beginning of the new day and the end of it. For members of the AA Fellowship, these guidelines are known as The Serenity Prayer, which begins and ends each meeting (Woydyłło, 2004).

As Krzysztof Wojcieszek (2009) notes, pragmatism during the recovery of addicts does not remove anything from the field of view that helps a person and assumes nothing in advance. All actions helping an addicted person to improve his or her life and increase security are acceptable in this case (Wojcieszek, 2009). In the process of psychotherapy, the pragmatic approach consists in understanding the patient and planning changes using the patient's capacities. In his pragmatic approach to therapy, Gerard Egan recommends "focusing on understanding the addict in many contexts of his life, planning to regain lost opportunities, taking into account his real possibilities. It is important to keep a balance between the support provided and the challenge set. In the model of competent assistance, actions should be driven by goals, not by problems" (Stradowski, 2015). On the other hand, Bill O'Connell focuses on the extraction of capacities: all the positive traits of an addict which can be used to build his success in coping with problems (Stradowski, 2015).

Alcoholics change their identity when interacting during AA meetings, and above all when they follow the principles of the 12 Steps of AA. Krzysztof Konecki (2015) points out that: "Identity [...] is constructed in action. The action is related to mental processes, where linguistic classifications of objects have a practical function and allow the individual to achieve specific effects. These effects are achieved through partial actions that take place when interacting with other people. These partial actions help achieve smaller goals, leading to full presentation, reception and evaluation, as well as self-assessment of the identity by the individual. Therefore, identity emerges in the contexts of the social circumstances of an individual's actions" (Konecki, 2015).

In an addicted person the observation of other addicts maintaining abstinence, struggling with everyday life problems, and at the same time coping with these problems without the use of alcohol stimulates the formation of a new identity: of an alcoholic, but free from the shame he or she used to experience; the identity that is understanding but above all understood; the identity that is self-aware of its deficits, but also the capacities it has, which have not been used so far, and the opportunities that arise from changing both the way of thinking and the resulting actions. Participation in the AA recovery program and observations made during AA meetings bring alcoholics to a specific paradox: they admit their weakness (uncontrolled alcohol consumption), but this is what generates their strength (by giving up 'fighting' alcohol they can channel all their activity at fixing their situation) (Kaczmarczyk, 2012).

Nevertheless, the 12 Steps of AA may be too complex for some individuals, and therefore useless, and this is not because of the deficits of this path, but rather because of a specific type of 'autonomy' that a person trying to stop drinking attempts to cultivate. In the fifth chapter of the Big Book of AA, the authors state: "Rarely have we seen a person fail who has thoroughly followed our path. Those who do not recover are people who cannot or will not completely give themselves to this simple program, usually men and women who are constitutionally incapable of being honest with themselves. There are such unfortunates. They are not at fault; they seem to have been born that way. They are naturally incapable of grasping and developing a manner of living which demands rigorous honesty. Their chances are less than average. There are those, too, who suffer from grave emotional and mental disorders, but many of them do recover if they have the capacity to be honest." (Alcoholics Anonymous, 2001). The phrase "They are not at fault; they seem to have been born that way" clearly resonates with the influence of Protestantism 
'assimilated' by the founders of AA, who were inspired by the Oxford Group, for which the principles of predestination were one of the dogmas of faith. Members of the Oxford Group believed that liberation from the alcohol obsession is an act of God's grace; it is a gift that can be granted by the Creator only if the alcoholic humbly gets on their knees and begs God for forgiveness (Osiatyński, 2007).

William G. Wilson admitted that salvation (recovery from addiction) is a gift. However, as he emphasized, personal participation is necessary to accept this gift. Wiktor Osiatynski aptly noted that the alcoholic, apart from asking for grace, has to work on themselves, and most importantly cooperate with others and share a personal experience with those who have not yet managed to decide to stop drinking (Osiatyński, 2007). Therefore, the more adequate phrase is: "those who cannot or will not completely give themselves to this simple program", which imposes on alcoholic's responsibility for making positive changes in their lives. These individuals were accurately described by Ewa Woydyłł: "[guidelines to recovery] are not found in the AA only by those who say that they want to recover but would prefer that the lion's share of the work be done for them by someone else. These are the people who believe more in medicines and tricks acting on them without their involvement than in personal work on themselves" (Woydyłło, 2007).

Some alcoholics are reluctant to join the AA Fellowship, arguing that its principles and effects are sectarian. However, the goal of the 12 Steps of AA is not to deprive the individual of autonomy, as it is done in sects; members can follow the program or not, in full or in part, or not accept it at all in practice. The principles of the Alcoholics Anonymous program are much simpler than all the initiatives taken in the past imposing strict rules on the individual and the whole society (Jasiński, 2008), which were found to be not very effective. It is true, however, that the rigorous observation of the principles presented in the 12 Steps can effectively protect an alcoholic from both relapse and death (Vaillant, 2005; Ceylan \& Metcalf-White, 2019).

The usefulness and spread of ideas promoting recovery from alcoholism are warranted by the fact that AA members cannot question these principles and universal rules accepted by the founders of the AA Fellowship: AA avoids having property ownership and rigorously refrains from soliciting support from sources other than the voluntary contributions of its members, which helps the organization to maintain independence. The AA Fellowship refrains from self-promotion, and it depends on the objective appraisals of outside observers and the testimonials of members during meetings (Gross, 2010). AA does not have a governing structure or charismatic leaders with infallible power, which helps minimize conflicts and, if necessary, also verifies people working in the Services whose task is to represent AA groups (Vaillant, 2005).

\section{Research Data}

To obtain empirical evidence of the effectiveness of the AA Fellowship may seem a difficult task because of the anonymity of its members. Nevertheless, researchers have repeatedly attempted to explore this environment and, with the principle of anonymity still maintained, they were able to make valuable observations supporting the effectiveness of the 12 Steps of AA, and helping to understand the circumstances that promote the recovery of alcoholics, often in cases considered hopeless.

Every three years since 1968 the General Service Office has surveyed Alcoholics Anonymous meetings in the United States and Canada to keep members informed on current trends in membership characteristics. In 2007, over 8,000 respondents participated in this survey, and one-third of them were women. These data indicate that, compared to previous years, the rate of women joining AA had increased (in the first survey women accounted for $22 \%$ of the studied population). The mean age of respondents was 47 years. Respondents declared taking part in two meetings per week on average, and the average period of maintained abstinence was 8 years; abstinence was longer than 10 years in $30 \%$ of respondents, $5-10$ years in $12 \%$, one to 5 years in $24 \%$, and $31 \%$ of respondents did not drink alcohol for less than one year. Almost half of the respondents joined the AA Fellowship following the suggestions of professionals, $33 \%$ were encouraged by another participant in meetings, $31 \%$ joined on their own, $24 \%$ were persuaded by family members, and $11 \%$ joined AA because they were obliged to do so by a court. Almost $80 \%$ of respondents declared cooperation with a sponsor, $74 \%$ informed their doctor about joining AA, almost two-thirds used the support of professionals both before joining AA and in the first years of membership, $86 \%$ of respondents considered professional assistance to be very important in the recovery process, and $74 \%$ indicated that this assistance influenced their decision to join Alcoholics Anonymous (Woronowicz, 2009).

In his research conducted among participants in AA meetings, Marcin Wnuk noted that involvement in the 12 Step Programme and participation in Fellowship activities facilitate the use of positive methods of coping with stress, which in turn increases the hope of AA members for improvement (Wnuk, 2008a). For individuals struggling with addiction the ability to cope with difficult situations without drinking alcohol, together with the hope that, like other observed participants in the meetings they will be able to overcome all barriers, helps in achieving greater 
satisfaction with maintained abstinence. The involvement in Fellowship activities and following the principles of the 12 Steps of AA can contribute to improving the lives of alcoholics (De Soto, O'Donnell, \& De Soto, 1989; Moos, Schaefer, Andrassy, \& Moos, 2001; Kelly, Magill, \& Stout, 2009; Wnuk, 2007a; Wnuk, 2008b). The spiritual aspect of the 12 Steps of AA plays an important role in the recovery process, and commitment to following this path is a mediating factor between spirituality and quality of life, and between the use of religious ways to reduce stress and achieving satisfaction with life (Wnuk, 2007b).

In his article, Jakub Trzebiatowski (2008) points out the differences regarding the physical and mental status and social functioning in the two compared groups - members of the AA Fellowship and patients of an addiction clinic who did not take part in AA meetings. Research data have revealed better mental and physical well-being in participants of AA meetings; findings confirmed the possibility of spiritual rebirth in a broad sense in those following the principles of the 12 Steps of AA (Trzebiatowski, 2008), the opportunity to improve marital relationships, increasing parental responsibility and competence, and finding fulfillment through professional life (Chappel \& DuPont, 1999; Greene \& Nguyen, 2012).

Data from surveys carried out by Paweł Bronowski show that members of the AA Fellowship compared to alcoholics not using this form of mutual aid indicated the following top values: self-fulfillment, internal balance, self-control, and self-confidence (Bronowski, 2001). These attitudes may facilitate recovery, but they require regular supervision during meetings, in which all manifestations of an improper control over one's life, and lack of humility towards the power of addiction can be verified in confrontation with the experience of other AA members who have also previously incorrectly assessed their abilities, and as a result, resumed drinking alcohol. In this case, the experiences of other people who started drinking alcohol again, and then rejoined the AA 12 Step program, have a pragmatic function; cases of breaking abstinence, and circumstances that led to a relapse, self-criticism of improper attitudes of people who have experienced mishaps, are the capital helping other AA members to recover (Kaczmarczyk, 2012).

A study conducted by Glińska, Zasada, Brosowska and Lewandowska (2010) among alcoholics revealed that the mutual aid groups of Alcoholics Anonymous were the main source of support for respondents; over $95 \%$ of respondents declared that participation in AA meetings helped them cope with relapses of the disease, improved their life situation, and helped in making amends to relatives and achieving forgiveness (Glińska et al., 2010).

\section{Summary}

George E. Vaillant argues that medical professionals have very limited means of facilitating long-term abstinence in alcoholics. He also indicates (by reference to conducted studies) that the AA Fellowship is the most effective long-term way to prevent relapse (Vaillant, 2005). The data presented above give only a partial description of the effects of membership in the AA Fellowship identified in studies conducted among its members. By following the 12 Steps of AA a significant number of alcoholics maintain abstinence and rebuild their often-devastated personality. The new freedom they gain implies a rational and adequate attitude that allows for telling the difference between good and evil, identifying the truth, and choosing it concerning other people (Kaczmarczyk, 2007; Kelly, Humphreys, \& Ferri, 2020). The described effects of the Alcoholics Anonymous Fellowship are unquestionable proof of the usefulness of the 12 Step Programme in recovery from addiction. Moreover, Woronowicz (2009) emphasized that the ideas of AA had a significant impact on public life:

- By spreading the principles of the AA Fellowship, the American Medical Association acknowledged alcoholism as a disease,

- Most therapeutic plans use the 12 Step Programme, and recommend participation in AA meetings to patients,

- People convicted by courts for driving under the influence of alcohol are ordered to attend AA meetings,

- Alcoholics attending AA meetings are engaged in the implementation of therapeutic programs,

- The training curriculum for addiction treatment specialists includes learning about the 12 Step Programme,

- Many other mutual aid programs have been developed based on the 12 Steps of AA (Woronowicz, 2009).

A popular text showing the utilitarian nature of the 12 Steps path is the Twelve Promises of AA, which are devoid of pathos and extravagance, and exemplify the pragmatism of the Alcoholics Anonymous Fellowship: "If we are painstaking about this phase of our development, we will be amazed before we are halfway through. We are going to know a new freedom and a new happiness. We will not regret the past nor wish to shut the door on it. We will comprehend the word serenity, and we will know peace. No matter how far down the scale we have gone, we will 
see how our experience can benefit others. That feeling of uselessness and self-pity will disappear. We will lose interest in selfish things and gain interest in our fellows. Self-seeking will slip away. Our whole attitude and outlook upon life will change. Fear of people and economic insecurity will leave us. We will intuitively know how to handle situations which used to baffle us. We will suddenly realize that God is doing for us what we could not do for ourselves. Are these extravagant promises? We think not. They are being fulfilled among us - sometimes quickly, sometimes slowly. They will always materialize if we work for them" (Alcoholics Anonymous, 2001).

The 12 Steps of AA help alcoholics in stopping the use of alcohol, changing the way of thinking, achieving emotional maturity, accepting responsibility for their thoughts, feelings, and behaviors, assist those unable to stop drinking, and fill the spiritual void caused by alcohol withdrawal (Osiatyński, 2013). Kurt Vonnegut once said that the 12 Steps of AA is humanity's greatest invention of the $20^{\text {th }}$ century. This view is likely shared by more than two million recovering addicts participating in AA meetings around the world, millions of their relatives and friends, and a difficult to estimate population living in the same community with alcoholics (Woronowicz, 2009; Humphreys, Blodgett, \& Wagner, 2014).

The usefulness of the 12 Steps of Alcoholics Anonymous is also proven by the fact that its principles have also been adopted by many other self-help groups: Narcotics Anonymous, Gamblers Anonymous, Gluttons Anonymous, Workaholics Anonymous, Drugs Anonymous, Nicotine Anonymous, and many other self-support organizations whose aim is, through interaction and sharing experiences, to gain understanding and support from people facing a particular problem, and to work on improving the quality of life, increasing life satisfaction, and development in a broad sense (Petry, 2003; Laudet, 2008; Kelly \& Yeterian, 2011; Tracy \& Wallace, 2016).

\section{Competing Interests Statement}

The authors declare that there are no competing or potential conflicts of interest.

\section{References}

Alcoholics Anonymous. (2001). Alcoholics Anonymous (4th ed). New York, NY: A.A. World Services, Inc.

Bettinardi-Angres, K., \& Angres, D. H. (2010). Understanding the Disease of Addiction. Journal of Nursing Regulation, 1(2), 31-37. https://doi.org/10.1016/S2155-8256(15)30348-3

Bronowski, P. (2001). Hierarchia wartości u członków wspólnoty Anonimowych Alkoholików. Alkoholizm $i$ Narkomania, 14(4), 499-509.

Broszkiewicz, P. (2012). Charlesa Sandersa Pierce'a koncepcja znaku względem pierce'owskiego pragmatyzmu. Śląskie Studia Filozoficzne, 11, 191-203.

Burak, A., Dembna, I., Cierzniakowska, K., Zacniewski, R., \& Popow, A. (2016). The patient under the influence of alcohol - Discriminated victim or aggressor? Alcoholism and Drug Addiction, 29(3), 131-152. https://doi.org/10.1016/j.alkona.2016.09.001

Ceylan, I., \& Metcalf-White, L. (2019). Perception of Spirituality among Substance Addicts with Incarceration Experience: A Phenomenological Study. Spiritual Psychology and Counseling, 4(3), 201-218. doi: 10.12738/spc.2019.4.3.084

Chappel, J. N., \& DuPont, R. L. (1999). Twelve-step and mutual-help programs for addictive disorders. The Psychiatric Clinics of North America, 22(2), 425-446. https://doi.org/10.1016/s0193-953x(05)70085-x

De Soto, C. B., O’Donnell, W. E., \& De Soto, J. L. (1989). Long-term recovery in alcoholics. Alcoholism, Clinical and Experimental Research, 13(5), 693-697. https://doi.org/10.1111/j.1530-0277.1989.tb00406.x

Dewey, J. (1950). Reconstruction in philosophy. New York: New American Library / Mentor Books.

Drozdowicz, Z. (2010). O racjonalności w religii i w religijności (raz jeszcze). Poznań: Wydawnictwo Naukowe UAM.

General Service Office. (2019). Estimates of A. A. Groups and Members as January 1, 2019. Retrieved from http://www.aa.org/assets/en_US/smf-53_en.pdf

Glińska, J., Zasada, J., Brosowska, B., \& Lewandowska, M. (2010). Czynniki demograficzne a formy otrzymanego wsparcia u osób uzależnionych od alkoholu. Problemy Pielegniarstwa, 18(3), 279-284.

Greene, G., \& Nguyen, T. D. (2012). The Role of Connectedness in Relation to Spirituality and Religion in a Twelve-Step Model. Review of European Studies, 4(1), 179-187. https://doi.org/10.5539/res.v4n1p179

Gross, M. (2010). Alcoholics Anonymous: still sober after 75 years. American Journal of Public Health, 100(12), 2361-2363. https://doi.org/10.2105/AJPH.2010.199349 
Humphreys, K., Blodgett, J. C., \& Wagner, T. H. (2014). Estimating the efficacy of Alcoholics Anonymous without self-selection bias: an instrumental variables re-analysis of randomized clinical trials. Alcoholism, Clinical and Experimental Research, 38(11), 2688-2694. https://doi.org/10.1111/acer.12557

James, W. (1920). Collected Essays and Reviews. New York, NY: Longmans, Green.

James, W. (1998). Pragmatism: A new name for some old ways of thinking. Warszawa: Wydawnictwo KR.

Jannasz, M. (2018). Alcoholics Anonymous Comes to Poland: The Founding of the Polish AA and the American Connection. European Journal of American Studies, 13(3), 1-14. https://doi.org/10.4000/ejas.13694

Jasiński, J. (2008). Ruch Trzeźwościowy w Stanach Zjednoczonych. Korzenie amerykańskiej prohibicji. Alkoholizm i Narkomania, 21(1), 65-94.

Kaczmarczyk, I. (2007). Co się dzieje w AA? Terapia Uzależnienia i Wspótuzależnienia, SE, 81-84.

Kaczmarczyk, I. (2012). Terapeutyczne oddziaływania Wspólnoty Anonimowych Alkoholików. In L. Grzesiuk \& H. Suszek (Eds.), Psychoterapia. Pogranicza (pp. 519-546). Warszawa: Wydawnictwo Eneteia.

Kelly, J. F., \& Yeterian, J. D. (2011). The role of mutual-help groups in extending the framework of treatment. Alcohol Research \& Health, 33(4), 350-355.

Kelly, J. F., Humphreys, K., \& Ferri, M. (2020). Alcoholics Anonymous and other 12-step programs for alcohol use disorder. Cochrane Database of Systematic Reviews, 3. doi: 10.1002/14651858.CD012880.pub2.

Kelly, J. F., Magill, M., \& Stout, R. L. (2009). How do people recover from alcohol dependence? A systematic review of the research on mechanisms of behavior change in Alcoholics Anonymous. Addiction Research \& Theory, 17(3), 236-259. https://doi.org/10.1080/16066350902770458

Knapik, T. (2012). Pragmatyzm w Polsce - wczesne reakcje, pierwsze wzmianki. IDEA - Studia nad struktura $i$ rozwojem pojęć filozoficznych, 24, 133-145.

Konecki, K. T. (2015). Anselm L. Strauss - pragmatyczne korzenie, pragmatyczne konsekwencje. Przeglą Socjologii Jakościowej, 11(1), 12-39.

Laudet A. B. (2008). The impact of alcoholics anonymous on other substance abuse-related twelve-step programs. Recent Developments in Alcoholism, 18, 71-89. https://doi.org/10.1007/978-0-387-77725-2_5

Mellibruda, J. (1997). Psycho-bio-społeczny model uzależnienia od alkoholu. Alkoholizm i Narkomania, 3(28), 277-306.

Mellibruda, J., \& Sobolewska-Mellibruda, Z. (2006). Integracyjna psychoterapia uzależnień. Teoria i praktyka. Warszawa: Instytut Psychologii Zdrowia PTP.

Montalto, M. (2015). Alcoholics Anonymous: One Treatment Program to Rule Them All? Journal of Alcoholism \& Drug Dependence, 3, 228. https://doi: 10.4172/23296488.1000228

Moos, R., Schaefer, J., Andrassy, J., \& Moos, B. (2001). Outpatient mental health care, self-help groups, and patients' one-year treatment outcomes. Journal of Clinical Psychology, 57(3), 273-287. https://doi.org/10.1002/jclp.1011

Osiatyński, W. (2007). Alkoholizm. I grzech, i choroba, i... Warszawa: Iskry.

Osiatyński, W. (2013). Drogowskazy. Warszawa: Iskry.

Petry, N. M. (2003). Patterns and correlates of Gamblers Anonymous attendance in pathological gamblers seeking professional treatment. Addictive Behaviors, 2003, 28(6), 1049-1062.

Ryszkowski, A., Wojciechowska, A., Kopański, Z., Brukwicka, I, Lishchynskyy, Y., \& Uracz, W. (2015). Walka z uzależnieniem alkoholowym. Journal of Clinical Healthcare, 1, 14-17.

Śliwowska, M. (2009). Pragmatyczna teoria prawdy. Retrieved from http://www.racjonalista.pl/kk.php/s,6365

Stradowski, M. (2015). Wielowymiarowa terapia osób uzależnionych od alkoholu i narkotyków jako wychowanie do wolności i odpowiedzialności. Fides et Ratio, 1(21), 279-295.

Szacki, J. (2007). Historia myśli socjologicznej. Warszawa: Wydawnictwo Naukowe PWN.

Taves, A. (2009). William James Revisited: Rereading the Varieties of Religious Experience in Transatlantic Perspective. Zygon, 44(2), 415-432.

Tracy, K., \& Wallace, S. P. (2016). Benefits of peer support groups in the treatment of addiction. Substance Abuse and Rehabilitation, 7, 143-154. https://doi.org/10.2147/SAR.S81535 
Trevisan, L. A., Boutros, N., Petrakis, I. L., \& Krystal, J. H. (1998). Complications of alcohol withdrawal: pathophysiological insights. Alcohol Health and Research World, 22(1), 61-66.

Trzebiatowski, J. (2008). Wybrane aspekty funkcji emocjonalno-ekspresyjnej Wspólnoty AA oraz programów terapeutycznych. Roczniki Socjologii Rodziny, 19, 173-195.

Trzebiatowski, J. (2014). Pomiędzy światem „czynnego alkoholizmu” a rzeczywistością zdrowienia. Mechanizmy (re)socjalizacyjne anonimowych alkoholików. Przegląd Socjologii Jakościowej, 10(1), 66-93.

Vaillant, G. E. (2005). Alcoholics Anonymous: cult or cure? The Australian and New Zealand Journal of Psychiatry, 39, 431-436. https://doi.org/10.1111/j.1440-1614.2005.01600.x

William James and Alcoholics Anonymous. (2013). Markings, 33(2). Retrieved from https://www.aa.org/newsletters/en_US/f-151-markings_fall-2013.pdf

Wnuk, M. (2007a). Abstynencja i długość pobytu w ruchu samopomocy a dobrostan psychiczny osób uzależnionych od alkoholu Mediacyjna rola Programu Dwunastu Kroków (1). Alkoholizm i Narkomania, 20(4), 395-416.

Wnuk, M. (2007b). Duchowy charakter Programu Dwunastu Kroków a jakość życia Anonimowych Alkoholików. Alkoholizm i Narkomania, 20(3), 289-301.

Wnuk, M. (2008a). Rola religijności dla nadziei Anonimowych Alkoholików. Polskie Forum Psychologiczne, 13(1), 33-49.

Wnuk, M. (2008b). Zaangażowane we Wspólnotę Anonimowych Alkoholików a jakość życia i długość abstynencji jej członków. Alkoholizm i Narkomania, 21(3), 235-245.

Wnuk, M., \& Marcinkowski, J. T. (2012). Alkoholizm - przegląd koncepcji oraz metod leczenia. Hygeia Public Health, 1(47), 49-55.

Wojcieszek, K. (2009). Profilaktyka używania substancji psychoaktywnych - wybrane problemy. In M. Jędrzejko (Ed.), Narkomania. Spojrzenie wielowymiarowe (pp. 309-330). Pułtusk-Warszawa: Akademia Humanistyczna im. A. Gieysztora - ASPRA-JR.

World Health Organization. (2018). Global status report on alcohol and health 2018. Geneva: World Health Organization.

Woronowicz, B. T. (1992) Historia wspólnoty Anonimowych Alkoholików i terapeutyczne walory Programu Dwunastu Kroków. Postępy Psychiatrii i Neurologii, 1, 191-198.

Woronowicz, B. T. (2009). Uzależnienia. Geneza, terapia, powrót do zdrowia. Warszawa: Media Rodzina \& Wydawnictwo Edukacyjne Parpamedia.

Woydyłło, E. (2004). AA w oczach psychologa. Arka, 46, 6-20.

Woydyłło, E. (2007). O nawrotach choroby. Terapia Uzależnienia i Wspótuzależnienia, SE, 69-73.

\section{Copyrights}

Copyright for this article is retained by the author(s), with first publication rights granted to the journal.

This is an open-access article distributed under the terms and conditions of the Creative Commons Attribution license (http://creativecommons.org/licenses/by/4.0/). 